\title{
PERANCANGAN SISTEM INFORMASI PENDAFTARAN PASIEN MENGGUNAKAN VB.NET PADA KLINIK PRATAMA RBG RZ BANDUNG
}

\author{
Johnson Sihombing ${ }^{1}$, Irwan Budi Irawan ${ }^{2}$ \\ Manajemen Informatika ${ }^{1,2}$ \\ Politeknik Piksi Ganesha Bandung \\ Jl. Jend. Gatot Subroto No. 301 Bandung 40274 \\ John97.sihombing@gmail.com ${ }^{1}$, bims.bs@ gmail.com ${ }^{2}$
}

\begin{abstract}
Abstrak
Klinik Pratama RBG RZ merupakan salah satu klink yang berlokasi di Bandung yang mana kegiatannya melayani kesehatan baik seperti pasien rawat jalan, pasien rawat inap, Poli Gigi dan ruang rawat inap pasien. Sisten mformasi yang ada di klinik yang sedang berjalan saat ini masih dilakukan secara manual sehingga mengakibatkan kurang maksimal dalam hal pelayanan.

Administrasi pendaftaran pasien di Klinik Pratama RBG RZ Bandung merupakan salah satu kegiatan yang utama dalam industri yang bergerak bidang pelayanan kesehatan, belum menggunakan teknologi komputer sebagai alat bantu pengelolaan data pasien dan data pembayaran oleh pasien.

Perencanaan pengembangan sistem yang penulis lakukan untuk sistem infomrasi pendaftaran pasien berbasis desktop adalah dnmgan menggunakan metode Waterfall. Sedangkan tools untuk perancangan sistem adalah metode/teknik yang disebut dengan Unified Modelling Language (UML). Untuk keperluan pengembangan aplikasi administrasi pedaftaran pasien, penulis $m$ suatu perangkat lunak yang sudah teruji kehandalannya dan banyak digunakan pengembang aplikasi saat ini yaitu VB.Net dengan editor berikut compiler nya Visual Studo 2013 dan database My SQL.

Uraian laporan akan membahas tentang kegiatankegiatan beserta produk-produk yang dihasilkan untuk tiap tahapan pengembangan. Data-data yang dibuthkan untuk perancangan sistem pendaftaran pasien terdiri atas : pendaftaran pasien, pasien, pemeriksan pasien, serta pembayaran yang dilakukan oleh pasien.
\end{abstract}

\section{Kata kunci :}

Sistem Informasi, Administrasi Pendaftaran Pasien, UML, VB.Net, My SQL.

\begin{abstract}
The RBG RZ Primary Clinic is one of the clinics located in Bandung where its activities serve good health such as outpatients, inpatients, dental clinics and inpatient rooms. Information system in the clinic that is currently running is still done manually so that it causes less than the maximum in terms of service.

Administration of patient registration at the $R B G$ $R Z$ Bandung Primary Clinic is one of the main activities in the industry which is engaged in health services, not yet using computer technology as a tool for managing patient data and payment data by patients.
\end{abstract}

System development planning that the writer did for desktop-based patient registration information system is using the Waterfall method. While the tools for system design are methods / techniques called Unified Modeling Language (UML). For the purposes of developing patient registration administration applications, the author of a software that has proven its reliability and is widely used by application developers today is VB.Net with the editor and compiler following its Visual Studo 2013 and My SQL database.

The report description will discuss the activities along with the products produced for each stage of development. The data required for the design of a 
patient registration system consists of: patient registration, patient examination, and patient payment

\section{Keywords:}

Information System, Patient Registration Administration, UML, VB.Net, My SQL.

\section{Pendahuluan}

\section{I.1 Latar Belakang}

Perkembangan teknologi informasi merupakan yang sangat pesat pada saat ini akan memudahkan manusia untuk dapat mengakses informasi secara cepat dan akurat baik secara individu maupun korporasi. Hal tersebut dapat terlaksana apabila kegiatan sistem yang sedang berjalan terlah beroperasi dengan baik.

Klinik Pratama RBG RZ merupakan suatu klinik yang berkegiatan dalam bidang pelayanan kesehatan untuk pasien rawat jalan, pasien rawat inap dan juga menyediakan ruang rawat inap. Hampir dalam segala kegiatan di atas, pengolahan datanya masih dilakukan secara manual. Hal tersebut mengakibatkan keterlambatan dalam pembuatan laporan dan pencarian data tertentu yang membutuhk an waktu yang relative cukup lama, termasuk juga dalam hal pengolahan data pendaftaran pasien. Dengan kondisi diatas, maka dibutuhkan suatu sistem terintegrasi dengan bantuan teknologi komputer untuk mengolah data pendaftaran pasien di Klinik Pratama RBG RZ Bandung.

Salah satu faktor yang penulis anggap perlu dilakukannya sistem yang terkomputerisasis adalah sistem tersebut akan memiliki kehandalan disbanding dengan cara-cara yang manual. Apalagi jika didukung oleh sumber daya manusia (SDM) yang bermutu. Oleh karena itu, peningkatan kualitas SDM adalah satu hal yang dianggap penting untuk mengoperasikan sstem yang nantinya bertujuan untuk proses pengambilan keputusan yang tepat bagi pihak manajemen klinik.

Agar proses rancang bangun dapat dilaksanakan dengan ekspektasi yang sesuai dengan perencanaan awal, penulis menggunakan program komputer, yaitu dengan menggunakan program VB.Net dengan database My SQL.

\section{I.2 Tujuan Penelitian}

Adapun tujuan dari Perancangan Sistem Informasi Pendaftaran Pasien di Klinik RBG RZ Bandung adalah untuk menghasilkan suatu sistem informasi yang berupa program aplikasi berbasis desktop yang dapat digunakan untuk mengolah data pendaftaran pasien. Aktivitas rancang bangun sistem terdiri atas : deskripsi masalah yang dihadapi, pengumpulan data sesuai kebutuhan, desain dan rekayasa perangkat lunak aplikasi, dan tahap terkhiir adalah kegiatan pengimplementasian dan testing perangkat lunak.

Dengan dibangunnya sistem informasi pendaftaran pasien ini, dapat menggantikan sistem manual yang sedang berjalan dan memberikan sebuah solusi atas kendala atau masalah yang selama ini dihadapi pihak Klinik Pratama RBG RZ Bandung.

\section{KAJIAN LITERATUR}

\section{II.1 Pengertian Klinik}

Menurut Peraturan Menteri Kesehatan Repubik Indonesia Nomor 9 Tahun 2014 Pasal 1, Klinik adalah fasilitas pelayanan kesehatan yang menyelenggarakan pelayanan kesehatan perorangan yang menyediakan pelayanan medis dasar dan atau spesialistik.

Jenis pelayanan pada klinik dapat dibedakan menjadi dua bagian Klinik Pratama (klinik yang menyelenggarakan pelayanan medik dasar) dan Klinik Utama .(klinik yang menyelenggarakan pelayanan medik spesialistik dan pelayanan medik dasar). Dibawah ini dapat dilihat perbedaan antara klinik pratama dan klinik utama :

1. Klinik pratama hanya melakukan pelayanan medis dasar, sedangkan klinik utama melayani pelayanan medis dasar dan spesialis;

2. Klinik pratama dipimpin oleh dokter atau dokter gigi, sedangkan klinik utama dipimpin oleh dokter spesialis atau dokter gigi spesialis;

3. Klinik pratama boleh melayani pasien rawat inap jika klinik tersebut adalah suatu bentuk badan usaha, sedangkan klinik utama dapat melakukan pelayanan rawat inap;

4. Klinik pratama memiliki tenaga medis paling sedikit dua orang dokter atau dokter gigi, sedangkan klinik utama diwajibkan memiliki satu dokter spesialis untuk tiap jenis poli penyakit yang ada di klinik tersebut. 
Disisi lain, bagi klinik pratama yang melaksanakan pelayanan rawat inap, maka klinik tersebut harus memiliki fasilitas pelayanan kesehatan yag memadai, di antaranya :

1. Memiliki ruang rawat inap sesuai ketentuan yang berlaku;

2. Tersedianya kasur (bed) untuk pasien rawat inap sebanyak 5-10 bed, dan lama inap si pasien dibatasi sampai 5 hari;

3. Persyaratan kualifikasi yang harus terpenuhi untuk tenaga dan keperawatan;

4. Memiliki tempat untuk nutrisi kesehatan para pasien.

\section{II.2 Sistem Pendaftaran}

Proses dari pendaftaran pasien merupakan suatu awal dari serangkaian kegiatan pelayanan kesehatan yang dilakukan oleh pihak klinik pada saat sang pasien datang berkunjung ke klinik. Kualitas pelayanan yang diberikan oleh petugas front office klinik harus membuat pasien merasa puas dan nyaman. Hal tersebut perlu dilakukan pihak klinik agar pasien dapat kembali berkunjung ke klinik jika mengalamai gangguan kesehatan lagi.

Pada umumnya pada saat pendaftaran di rumah sakit, status pasien akan berubah menjadi :

1. Pasien rawat jalan

Disebut demikian dikarenakan setelah pemeriksaan oleh dokter, kondisi pasien masih dalam keadaan normal.

2. Pasien rawat inap

Kesehatan pasien perlu ditangani oleh dokter spesialis secara intensif.

3. Pasien menjalani perawatan UGD buruk.

Kesehatan pasien sudah dalam keadaan yang

Kegiatan pada pelayanan kesehatan untuk rawat jalan adalah pasien tersebut telah terdaftar sebagai pasien rawat jalan di rumah sakit. Dengan kata lain, pasien tidak perlu dirawat di rumah sakit (Abdelhak, 2001). Menurut Surat Keputusan Menteri Kesehatan RI No. 560/Menkes/SK/IV/2003 tentang tarif perjan rumah sakit bahwa rawat jalan adalah pelayanan kesehatan untuk pasien setelah dokter rumah sakit melakukan tindakan-tindakan observasi, diagnosa jenis penyakit pasien, dan pemulihan. Menurut dirjen Yanmed (2006:34), penerimaan pasien rawat jalan dinamakan TPP RJ (Tempat Penerimaan Pasien Rawat Jalan), yangn penerimaan pasien yang akan berobat ke poliklinik terkait sesuai jenis penyakit yang di idap pasien tersebut.

Apabila seorang pasien berkunjung ke rumah sakit, maka jenis kunjungan dapat dibedakan menjadi dua bagian :

1. Pasien Baru, adalah kunjungan pertama kali pasien ke rumah sakit untuk pemeriksaan kesehatan.

2. Pasien Lama, adalah pasien yang pernah minimal sekali berkunjung untuk berobat ke rumah sakit.

\section{II.3 Sistem Informasi Registrasi}

Merupakan suatu sistem informasi berupa aplikasi pendaftaran pada saat kunjungan pasien di rumah sakit/klinik yang bertujuan untuk mengelola data pasien baru dan pasien lama untuk semua jenis kategori pendaftaran pasien. Dengan sistem tersebut, pihak rumah sakit/klinik dapat mengetahui penyajian informas tentang jumlah kunjungan pasien ke polikinik yang ada di tempat tersebut serta memudahkan untuk pembuatan laporan (Rustyanto, 2011).

\section{II.4 Pasien}

\section{II.4.1 Pengertian pasien}

Pasien adalah seorang yang kondisi fisik atau mentalnya agak kurang sehat/normal sehingga perlu dilakukan pengobatan oleh tenaga medis terkait, yang dikemukakan oleh Prabowo (dalam Wilhamda, 2011). Sedangkan (Aditama, 2002) berpendapat bahwa pasien adalah seorang yang memerlukan pengobatan di rumah sakit.

Berdasarkan pendapat-pendapat tersebut diatas, maka penulis mengambil kesimpulan bahwa pasien adalah seorang yang kondisi fisik atau mentalnya agak kurang sehat/normal sehingga perlu dilakukan pengobatan yang ditetapkan oleh tenaga kesehatan atau para medis yang ada dirumah sakit.

\section{II.4.2 Kewajiban Pasien}

Menurut UU No.44 Tahun 2009 : UU tentang Rumah Sakit ndengan kewajiban pasien yakni kewajiban rumah sakit untuk pembertian pelayanan 
kesehatan terhadap pasien. Menurut (UU No. 29 Tahun 2004 : UU tentang Praktik Kedokteran), pasien mempunyai kewajiban untuk :

1. Menginformasikan secara detail tentang penyakit yang di idap kepada dokter terkait.

2. Patuh terhadap anjuran dari petugas kesehatan yang ada.

3. Patuh terhadap prosedur dan ketentuan yang ada di rumah sakit pada saat pemeriksaan kesehatan.

4. Patuh terhadap prosedur dan ketentuan yang ada di rumah sakit pada saat pemeriksaan kesehatan.

Berdasarkan UU RI No.38 Tahun 2014 dalam praktik keperawatan, maka pasien mempunyai kewajiban :

1. Menginformasikan secara detail tentang penyakit yang di idap kepada dokter terkait.

2. Patuh terhadap anjuran dan nasehat petugas kesehatan (perawat).

3. Patuh terhadap prosedur dan ketentuan yang ada di rumah sakit pada saat pemeriksaan kesehatan.

4. Membayar biaya pengobatan setelah penerimaan pelayanan kesehatan.

\section{II.5 Hak Pasien}

Substansi interaksi antara dokter dan pasien bukanlah tentang objek kesembuhan pasien, tetapi lebih ditekankan kepada mencari cara pengobatan yang sesuai untuk kesembuhan pasien. Dalam hubungan tersebut, pasien berhak atas informasi tentang kondisi kesehatan pasien yang terdiri dari : analisa penyakit yang ada di tubuh pasein, tindakan medis yang relevan, terapi-terapi kesehatan yang dibutuhkan, serta usaha-usaha penyembuhan lainnya. Dokter harus memberikan informasi secata rinci dan lengkap kepada pasiennya. Hal tersebut sangat berkaitan dan untuk keperluan pengambilan keputusan bagi dokter untuk membuat tindakan selanjutnya atas persetujuan pasien. Seorang pasien juga memliki hak rahasia kedokeran, yaitu hak pasien untuk dirahasiakan tentang jenis dan kronologis penyaktinya meski si pasien telah meninggal dunia. Jika pasien merasa kurang puas atas informasi yang diberikan oleh dokter pertma, maka pasien juga berhak untuk memeriksa kesehatannya ke dokter lain, sehingga keterangan penyakit pasien menjadi lebih akurat. Hak lainnya adalah rekam medik, yang merupakan catatan medis pasien dari saat pertama kali berkunjung di rumah sakit hingga pemeriksaan terakhir oleh dokter.

\section{II.6 Rekam Medik}

\section{II.6.1 Pengertian Rekam Medik}

Menurut Peraturan Menteri Kesehatan Nomor : 749a/MenKes/Per/XII/1989 tentang Rekam Medik, Rekam Medik adalah suatu dokumen yang berisi catatan-catatan tentang identitas pasien, pemeriksaan, pengobatan, tindakan kepada pasien pada sarana pelayanan kesehatan. Untuk melengkapi rekam medik harus dimiliki data yang cukup tertulis dalam rangkaian kegiatan guna menghasilkan diagnosis, jaminan dan pengobatan dan hasil akhir (SK Men PAN No. 135 tahun 2002).

\section{II.6.2 Pengelolaan Rekam Medik}

Pengelolaan rekam medik di rumah sakit biasanya dilakukan oleh Manajemen Rekam Medik, selanjutnya manajemen rekam medik telah berkembang menjadi manajemen informasi kesehatan dengan dukungan perkembangan teknologi. Rekam medik bukan lagi sekedar membuat ringkasan pasien keluar, laporan perkembangan, lembar perintah dokter, atau resume.

Semua informasi yang dihasilkan tentang seorang pasien dalam fasilitas kesehatan harus digolongkan sebagai bagian dari rekam medik. Manajemen informasi kesehatan tidak hanya mengumpulkan data pasien di fasilitas tersebut (misalnya klinik), tetapi juga melindungi dan menjaga kerahasiaannya, melakukan interpretasi, dan menganalisanya untuk membuat keputusan.

\section{II.6.3 Metode Rational Unified Process (Rup)}

Metode yang digunakan penulis untuk pengembangan perangkat lunak adalah dengan metode Rational Unified Process (RUP), yaitu perancangan perangkat lunak yang dilakukan secara kontinu/itersi, dengan penekanan yang lebih ke arah pemecahan kasus (use case driven). RUP merupakan suatu proses rancang bangun software yang memiliki keunggulan : identikasi maslah pendefinisian masalah yang lebih baik dan struktur program yang tepat.

Proses pengulangan/iteratif pada RUP secara global dapat dlihat sebagai berikut : 


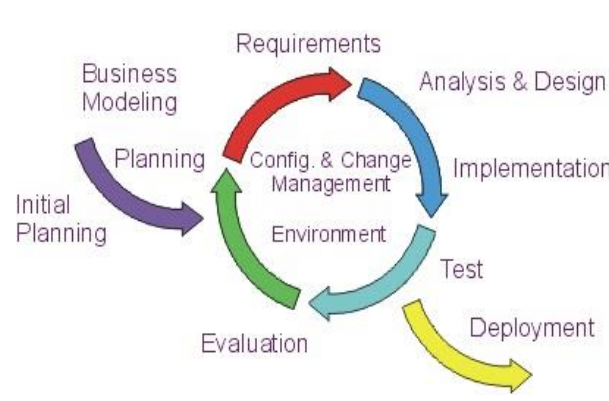

Gambar 1 Proses iteratif RUP

\section{II.7 Penelitian Terkait}

Penulis dalam penelitiannya menelaah penelitian lain yang juga menghasilkan aplikasi sejenis. Hal ini bertujuan untuk melihat segi kemanfaatan dari aplikasi yang telah dihasilkan oleh penulis. Penulis menyajikan perbandingan tersebut dalam Tabel 1.

Tabel 1 Penelitian Terkait

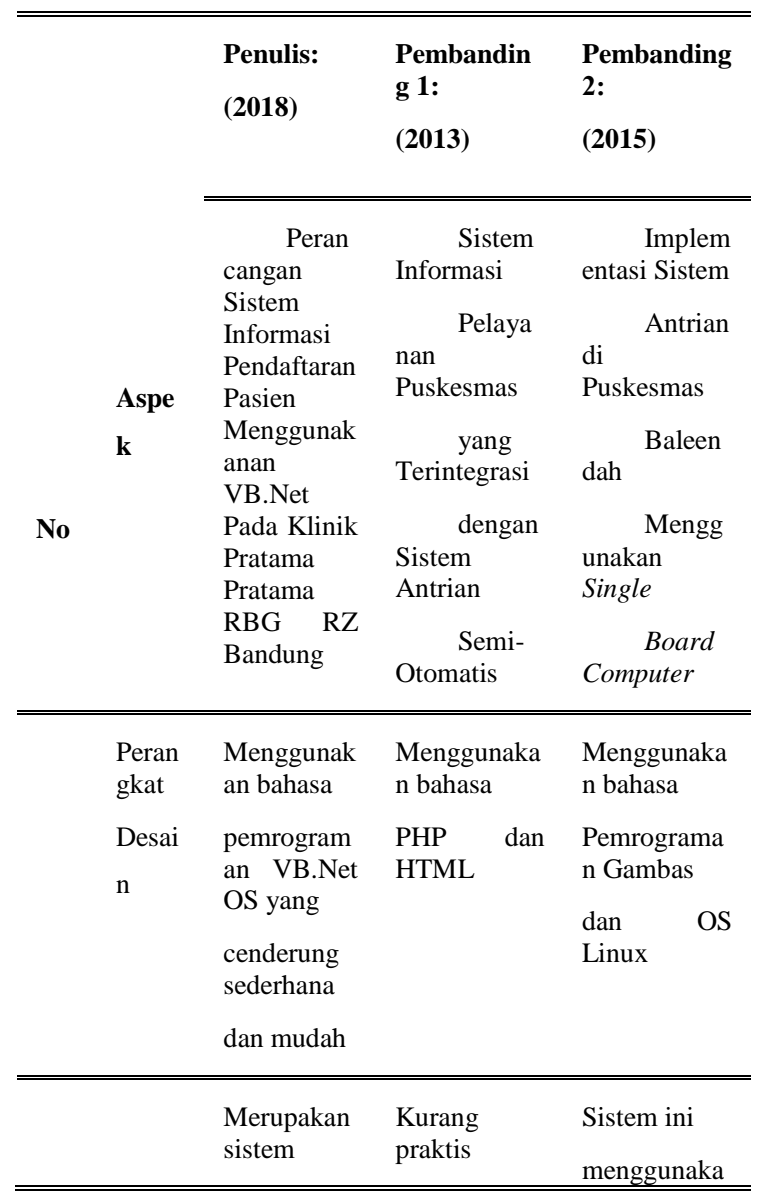

\begin{tabular}{|c|c|c|c|}
\hline \multirow{10}{*}{$\begin{array}{l}\text { Kepra } \\
\text { ktisan }\end{array}$} & $\begin{array}{l}\text { berbasis } \\
\text { desktop } \\
\text { sehingga } \\
\text { bisa } \\
\text { beroperasi }\end{array}$ & $\begin{array}{l}\text { karena } \\
\text { perangkat ini } \\
\text { harus } \\
\text { terhubung } \\
\text { dengan }\end{array}$ & $\begin{array}{l}\text { n koneksi } \\
\text { internet, } \\
\text { sehingga } \\
\text { apabila tidak } \\
\text { ada }\end{array}$ \\
\hline & $\begin{array}{l}\text { kapan saja } \\
\text { tanpa }\end{array}$ & internet, jika & jaringan \\
\hline & $\begin{array}{l}\text { ketergantun } \\
\text { gan dengan }\end{array}$ & $\begin{array}{l}\text { maka sistem } \\
\text { tidak akan }\end{array}$ & $\begin{array}{l}\text { koneksi } \\
\text { internet }\end{array}$ \\
\hline & $\begin{array}{l}\text { koneksi } \\
\text { internet } \\
\text { selain }\end{array}$ & berjalan. & $\begin{array}{l}\text { terganggu, } \\
\text { maka }\end{array}$ \\
\hline & $\begin{array}{l}\text { itu aplikasi } \\
\text { ini tidak }\end{array}$ & & $\begin{array}{l}\text { sistem tidak } \\
\text { bisa }\end{array}$ \\
\hline & $\begin{array}{l}\text { memerluka } \\
\text { n suara dari }\end{array}$ & & $\begin{array}{l}\text { bekerja. } \\
\text { Kurang }\end{array}$ \\
\hline & $\begin{array}{l}\text { petugas } \\
\text { secara } \\
\text { langsung }\end{array}$ & & $\begin{array}{l}\text { praktis } \\
\text { karena } \\
\text { petugas }\end{array}$ \\
\hline & $\begin{array}{l}\text { karena } \\
\text { suara } \\
\text { pemanggil }\end{array}$ & & $\begin{array}{l}\text { harus } \\
\text { memanggil } \\
\text { dengan suara }\end{array}$ \\
\hline & $\begin{array}{l}\text { dihasilkan } \\
\text { dari } \\
\text { aplikasi }\end{array}$ & & $\begin{array}{l}\text { langsung } \\
\text { dengan } \\
\text { menekan }\end{array}$ \\
\hline & tersebut & & $\begin{array}{l}\text { tombol } \\
\text { wireless. }\end{array}$ \\
\hline \multirow{5}{*}{$\begin{array}{l}\text { Ruan } \\
\text { g } \\
\text { Lingk } \\
\text { up }\end{array}$} & $\begin{array}{l}\text { Mencakup } \\
4 \text { ruang }\end{array}$ & $\begin{array}{l}\text { Hanya } \\
\text { mencakup } 3\end{array}$ & \multirow{5}{*}{$\begin{array}{l}\text { Hanya } \\
\text { diterapkan } \\
\text { pada } 2 \text { ruang } \\
\text { dari yaitu } \\
\text { poli umum } \\
\text { bayar dan } \\
\text { poli umum } \\
\text { ASKES }\end{array}$} \\
\hline & $\begin{array}{l}\text { yaitu, Poli } \\
\text { Umum, Pol }\end{array}$ & $\begin{array}{l}\text { ruang yaitu, } \\
\text { loket }\end{array}$ & \\
\hline & $\begin{array}{ll}\text { Gigi, } & \text { Poli } \\
\text { Gizi, } & \text { dan } \\
\text { Poli } & \end{array}$ & $\begin{array}{l}\text { (Pendaftaran } \\
\text { ), Bagian }\end{array}$ & \\
\hline & & $\begin{array}{l}\text { Pemeriksaan } \\
\text { umum, }\end{array}$ & \\
\hline & & dan Poli gigi. & \\
\hline
\end{tabular}

\section{Metodologi Penelitian}

\section{III.1 Pemodelan Bisnis}

Pada tahap ini, penulis melakukan komunikasi langsung dengan pihak Klinik Pratama RBG RZ Bandung. Komunikasi yang dilakukan berupa wawancara dengan General Affair, Dokter, Petugas RMFO (Rekam Medis Front Office). Administrasi, Keuangan dan Apotik. Berikut ini adalah diagram aktivitas pendaftaran pasien pada klinik : 


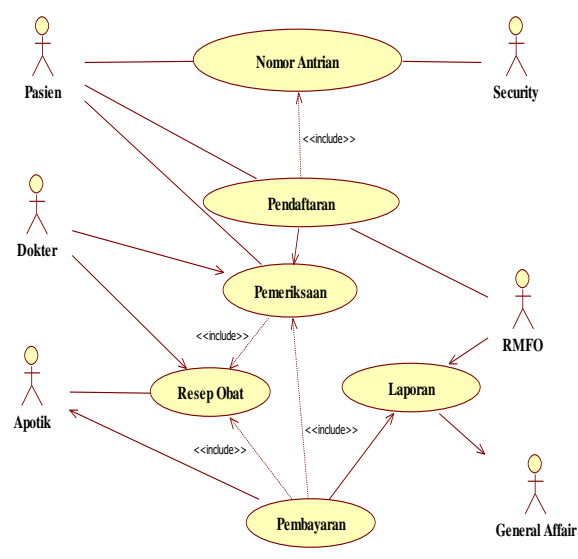

Gambar II. Diagram Aktivitas Pendaftaran Pasien

\section{III.2 Pengumpulan Kebutuhan}

Kebutuhan fungsional dan kebutuhan nonfungsional adalah dua elemen yang dibutuhkan dalam pengembangan perangkat lunak :

Tabel 2. Kebutuhan Fungsional

\begin{tabular}{|c|c|c|}
\hline No. & $\begin{array}{l}\text { Kebutuhan } \\
\text { Fungsional }\end{array}$ & Dilakukan \\
\hline 1 & $\begin{array}{lr}\text { Sistem } & \text { harus } \\
\text { melakukan } & \text { login } \\
\text { terlebih } & \text { dahulu } \\
\text { sebelum } & \text { dapat } \\
\text { diakses } & \end{array}$ & $\begin{array}{l}\text { Petugas, dokter, } \\
\text { apoteker, kepala klinik, } \\
\text { administrasi } \\
\text { melakukan login } \\
\text { terlebih dahulu }\end{array}$ \\
\hline 2 & $\begin{array}{l}\text { Sistem harus } \\
\text { mampu menerima } \\
\text { pendaftaran } \\
\text { pasien baru }\end{array}$ & $\begin{array}{lr}\text { Petugas melakukan } \\
\text { pendaftaran } \\
\text { baru }\end{array}$ \\
\hline 3 & $\begin{array}{l}\text { Sistem } \\
\text { mampu melakukan } \\
\text { rekam medis pasien }\end{array}$ & $\begin{array}{l}\text { Dokter melakukan } \\
\text { rekam medis pasien. }\end{array}$ \\
\hline 4 & $\begin{array}{l}\text { Sistem } r \text { harus } \\
\text { mampu menyimpan } \\
\text { data tindakan } \\
\text { medis yang telah } \\
\text { dilakukan }\end{array}$ & $\begin{array}{l}\text { Dokter melakukan } \\
\text { tindakan medis dan } \\
\text { disimpan dalam sistem }\end{array}$ \\
\hline 5 & $\begin{array}{lr}\text { Sistem } & \text { harus } \\
\text { mampu } & \text { mengecek } \\
\end{array}$ & $\begin{array}{l}\text { Apoteker menginput } \\
\text { obat yang masuk serta }\end{array}$ \\
\hline
\end{tabular}

\begin{tabular}{|c|c|c|}
\hline No. & $\begin{array}{l}\text { Kebutuhan } \\
\text { Fungsional }\end{array}$ & $\begin{array}{l}\text { Yang Dilakukan } \\
\text { Aktor }\end{array}$ \\
\hline & stok obat & $\begin{array}{lll}\begin{array}{l}\text { pengecekan } \\
\text { gudang }\end{array} & \text { stok } & \text { di } \\
\end{array}$ \\
\hline 6 & $\begin{array}{l}\text { Sistem harus } \\
\text { mampu } \\
\text { mengeluarkan } \\
\text { laporan klinik }\end{array}$ & $\begin{array}{l}\text { Kepala Klinik } \\
\text { melakukan pencarian } \\
\text { laporan klinik per } \\
\text { periode yang diberikan }\end{array}$ \\
\hline 7 & $\begin{array}{lr}\text { Sistem } r & \text { harus } \\
\text { menginput jumlah } \\
\text { pembayaran }\end{array}$ & $\begin{array}{lr}\text { Admin meyimpan data } \\
\text { nominal pembayaran, } \\
\text { lalu mencetak kwitansi } \\
\text { pembayaran dan } \\
\text { menyerahkannya } \\
\text { pasien }\end{array}$ \\
\hline
\end{tabular}

Tabel 3. Kebutuhan Non Fungsional

\begin{tabular}{|c|c|c|}
\hline No. & Non-Fungsional & $\begin{array}{l}\text { Yang Dilakukan } \\
\text { Aktor }\end{array}$ \\
\hline 1 & Operasional & $\begin{array}{lr}\text { Sistem } & \text { Operasi: } \\
\text { Windows 7/64 bit; } & \text { Visual Studio 2013; } \\
\text { Web Server: Apache; } & \text { Apataber Server: } \\
\text { Database } & \text { MySQL; XAMPP versi } \\
\text { 1.7.3 dengan support } \\
\text { PhpMySQL. }\end{array}$ \\
\hline 2 & Keamanan & $\begin{array}{lr}\text { Sistem aplikasi dan } \\
\text { database } & \text { dilengkapi } \\
\text { dengan } & \text { password; } \\
\text { dilengkapi } & \text { dengan } \\
\text { CCTV di ruang tunggu }\end{array}$ \\
\hline 3 & Informasi & $\begin{array}{lr}\text { Penyajian } & \text { informasi } \\
\text { tentang prosedur dan } \\
\text { ketentuan } & \text { untuk } \\
\text { proses } & \text { pendaftaran } \\
\text { pasien. } & \text { digunakan } \\
\text { untuk } & \\
\end{array}$ \\
\hline
\end{tabular}

Johnson Sihombing, Irwan Budi Irawan 


\section{Analisis dan Perancangan}

Penulis menggunakan use case diagram untuk mengrambarkan aktivitas-aktivitas antara user dan sistem yang sedang berjalan saat ini.

Pengguna sistem rkandan interaksi antara pengguna dengan sistem maupun interaksi antar pengguna. Diagram use case digunakan untuk mengetahui kegiatan untuk tiap elemen yang terlibat di dalamnya. Use case diagram untuk sistem informasi pendaftaran pasien menggunakan VB.Net di Klinik Pratama RBG RZ adalah sebagai berikut .:

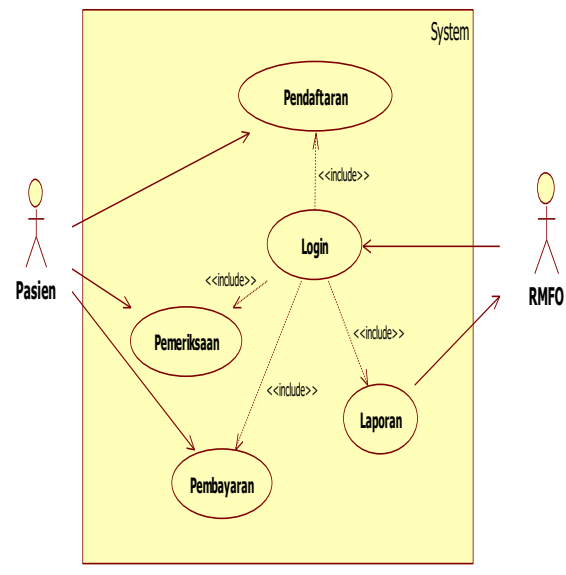

Gambar 2 Diagram Use case Pendaftaran Pasien

Adapun rancangan basis data yang dibutuhkan untuk sistem informasi pendaftaran pasien menggunakan VB.Net di Klinik Pratama RBG RZ dapat dilihat di bawah ini .:

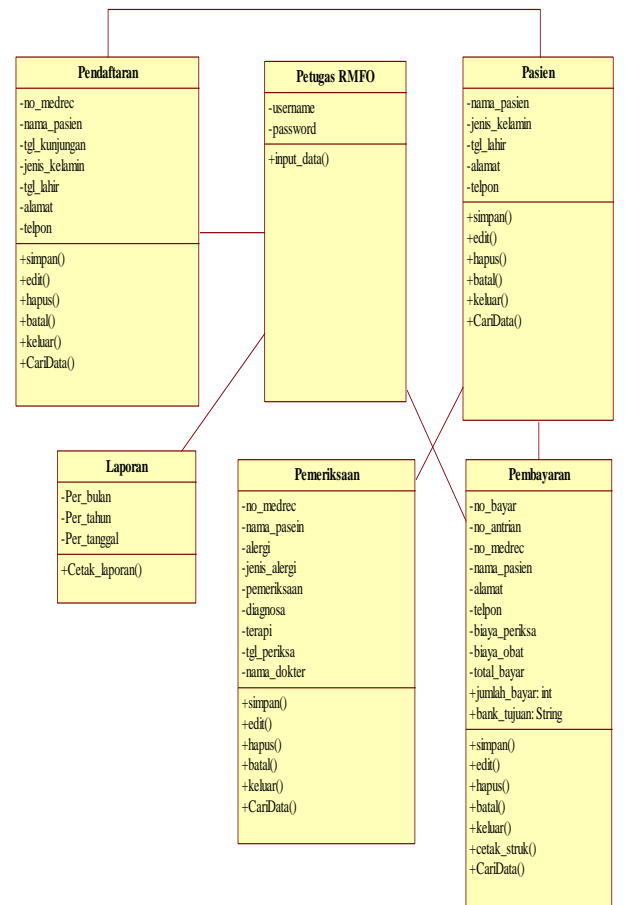

Gambar 3 Diagram class

\section{IV.1 Implementasi Antar Muka}

Hasil penelitian yang dilakukan penulis pada tahap ini dapat dilihat pada bentuk-bentuk gambar yang akan ditampilkan dibawah ini.

Pada gambar V menampilkan form Login yang merupakan tampilan awal dari Sistem Informasi Pendaftaran Pasien Klinik Pratama RBG RZ Bandung. Fom Login berfungsi agar petugas administras dapat mengakses sistem. 


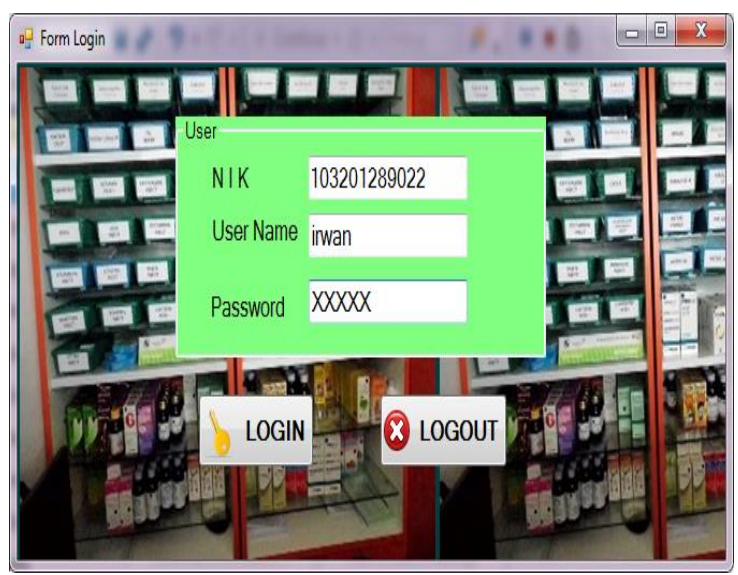

Gambar 4 Tampilan Form Login

Gambar 4 menunjukkan tampilan form baru setelah login yang merupakan Menu Utama sistem informasi pendaftaran pasien menggunakan VB.Net di Klinik Pratama RBG RZ Bandung. Pada dialog screen ini tersedia menu-menu Data Master, Proses, Laporan dan menu Keluar dari sistem.

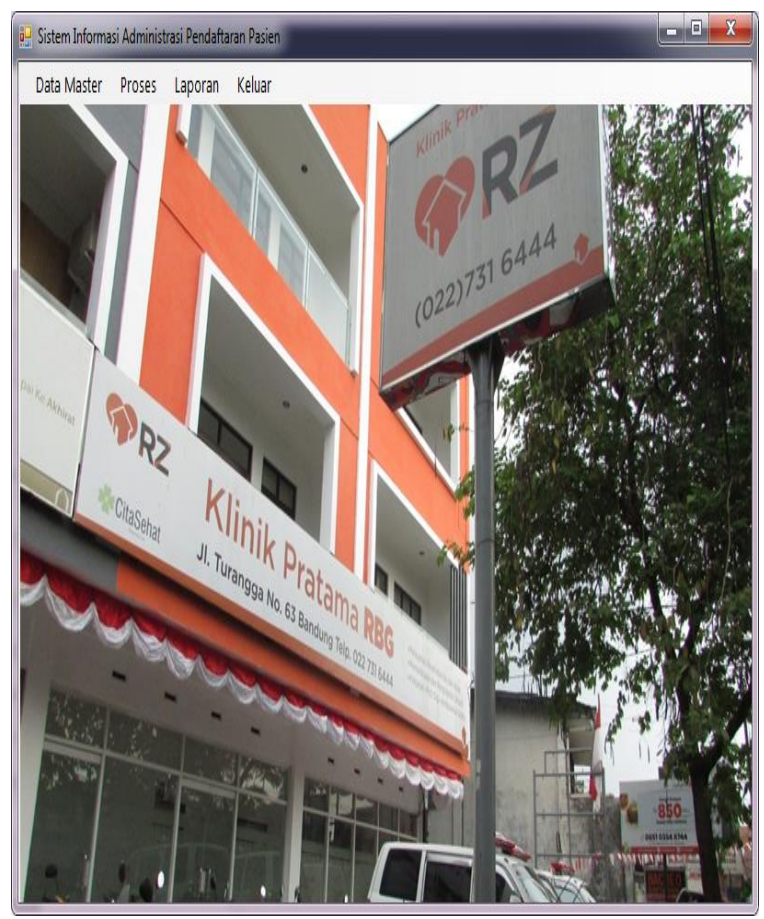

Gambar 5 Tampilan Menu Utama

Pada menu Data Master ada sub menu Pendaftaran Pasien dengan bentuk form di bawah ini :

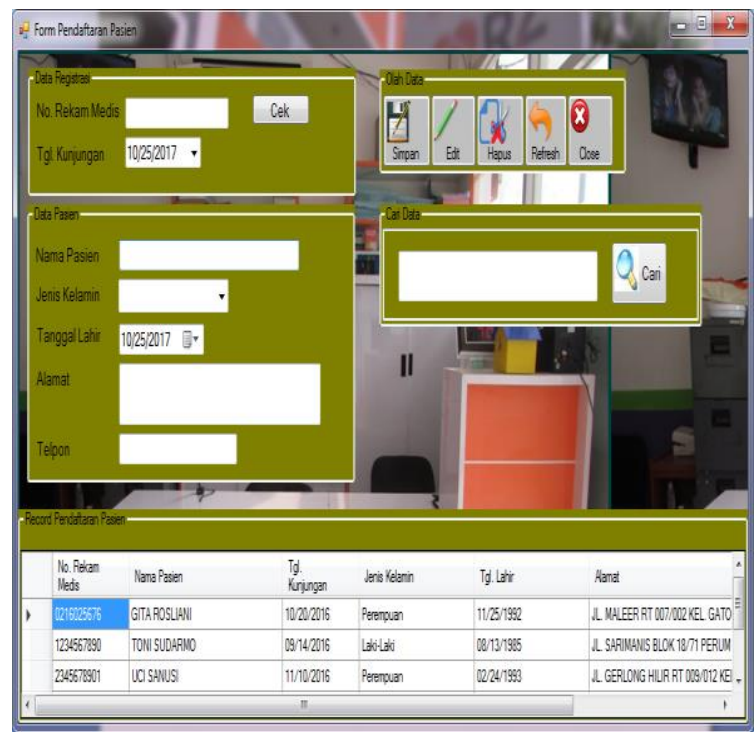

Gambar 6 Form Pendaftaran Pasien

Sedangkan pada menu Proses ada sub menu Pemeriksaan Pasien dan sub menu Pembayaran dengan bentuk-bentuk form sebagai berikut :

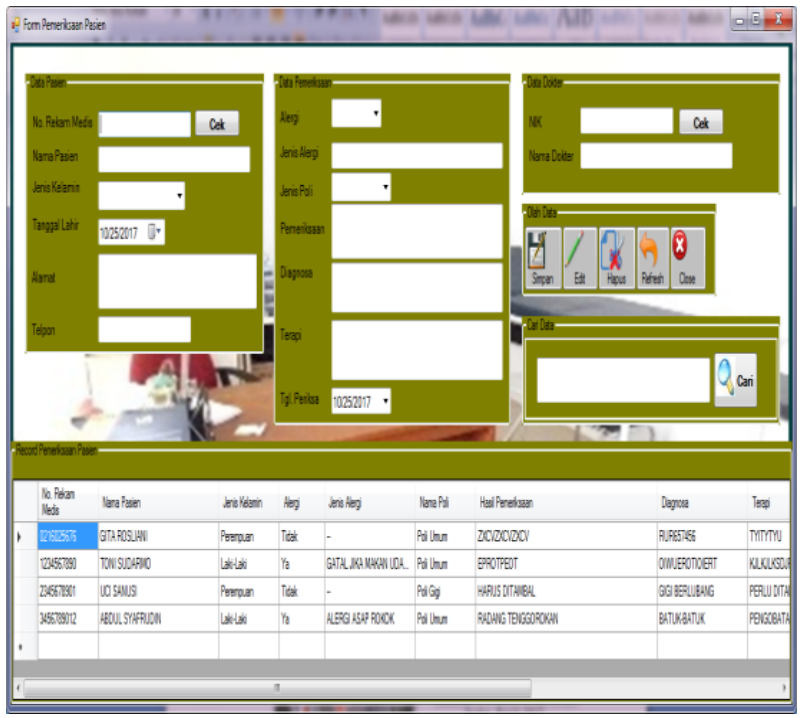

Gambar 7 Form Pemeriksaan Pasien 


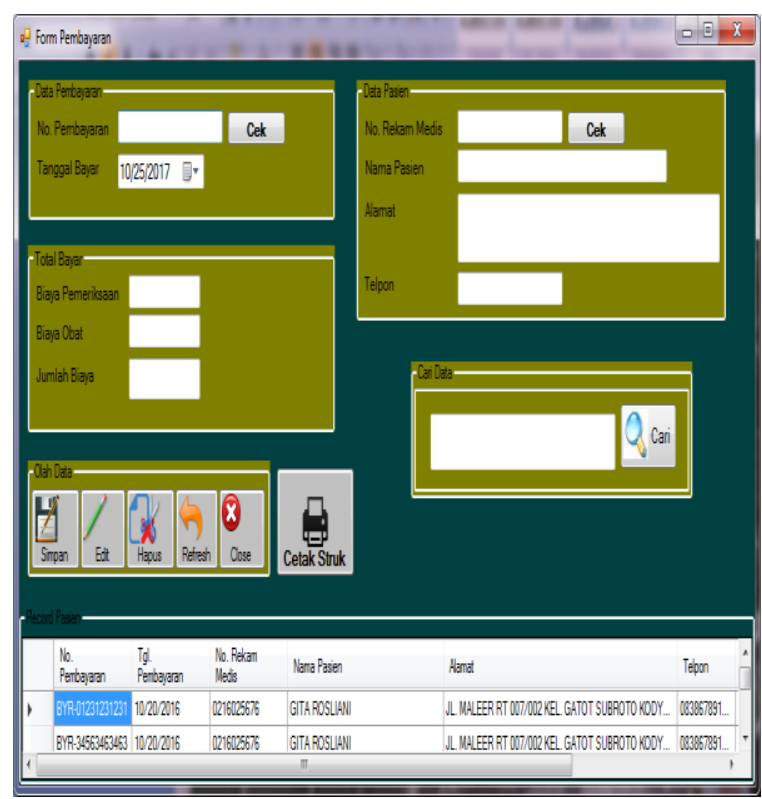

Gambar 8 Form Pembayaran

Setelah petugas administrasi menginput data pembayaran, maka pasien akan membayar biaya pemeriksaan berikut biaya pembelian obat. Petugas tersebut akan membuat struk bukti pembayaran seperti berikut :

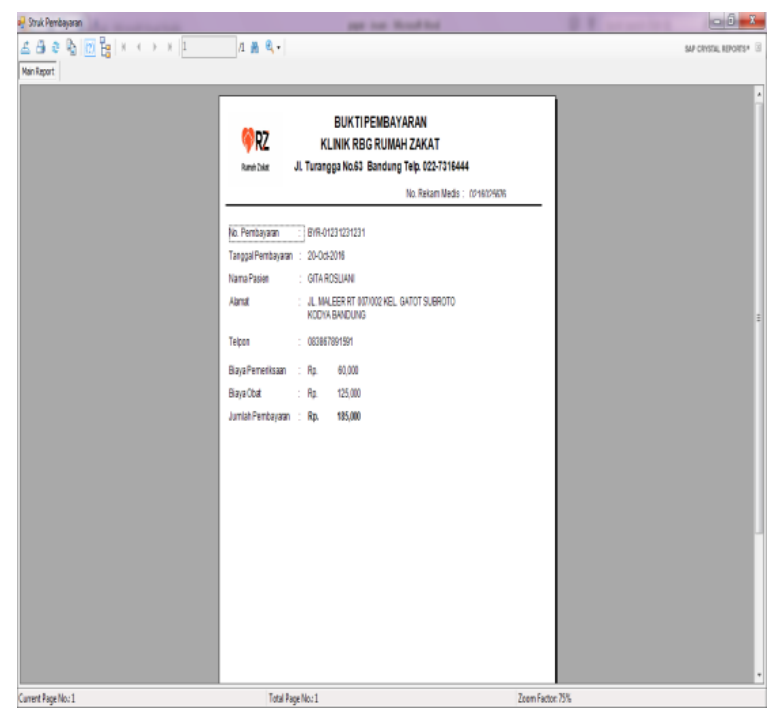

Gambar 9 Struk Bukti Pembayaran

\section{IV.2 Hasil Pengujian}

Pengujian terhadap aplikasi yang dibangun ini. menggunakan metode Black Box, yang merupakan suatu prose pengujian sistem terhadap fungsi-fungsi yang ada dalam sistem untuk mengetahaui hasil ouput dari fungsi-fungsi terebut.

Tabel 2 Hasil Pengujian

\begin{tabular}{|c|c|c|c|c|}
\hline $\begin{array}{l}N \\
o\end{array}$ & $\begin{array}{l}\text { Yang } \\
\text { Diuji }\end{array}$ & $\begin{array}{l}\text { Proses } \\
\text { Penguji } \\
\text { an }\end{array}$ & $\begin{array}{l}\text { Ekspetas } \\
\text { i } \\
\text { Hasil }\end{array}$ & $\begin{array}{l}\text { Hasi } \\
\text { l } \\
\text { Peng } \\
\text { ujia } \\
n\end{array}$ \\
\hline & $\begin{array}{l}\text { Penguji } \\
\text { an } \\
\log 1 \mathrm{n} \\
\text { admin }\end{array}$ & $\begin{array}{l}\text { Masukan } \\
\text { usernam } \\
\text { e dan } \\
\text { password }\end{array}$ & $\begin{array}{l}\text { Jika } \\
\text { username } \\
\text { dan } \\
\text { password } \\
\text { salah } \\
\text { maka } \\
\text { login } \\
\text { gagal . } \\
\text { Begitu } \\
\text { pula } \\
\text { sebalikny } \\
\text { a }\end{array}$ & $\begin{array}{l}\text { Gaga } \\
\text { l } \\
\text { login } \\
\text { admi } \\
n\end{array}$ \\
\hline & $\begin{array}{l}\text { Penguji } \\
\text { an } \\
\text { input } \\
\text { data } \\
\text { pasien }\end{array}$ & $\begin{array}{c}\text { input } \\
\text { data pasien }\end{array}$ & $\begin{array}{l}\text { Jika } \\
\text { pengisian } \\
\text { data } \\
\text { pasien } \\
\text { masuk } \\
\text { semua } \\
\text { datanya }\end{array}$ & $\begin{array}{l}\text { Data } \\
\text { pasie } \\
\mathrm{n} \\
\text { tersi } \\
\text { mpan }\end{array}$ \\
\hline & $\begin{array}{l}\text { Penguji } \\
\text { an } \\
\text { input } \\
\text { data } \\
\text { pasien }\end{array}$ & $\begin{array}{c}\text { input } \\
\text { data pasien }\end{array}$ & $\begin{array}{l}\text { Jika } \\
\text { pengisian } \\
\text { data } \\
\text { pasien } \\
\text { masuk } \\
\text { semua } \\
\text { datanya }\end{array}$ & $\begin{array}{l}\text { Data } \\
\text { komp } \\
\text { onen } \\
\text { tidak } \\
\text { tersi } \\
\text { mpan }\end{array}$ \\
\hline & $\begin{array}{l}\text { Penguji } \\
\text { an } \\
\text { input } \\
\text { data } \\
\text { pasien }\end{array}$ & $\begin{array}{c}\text { input } \\
\text { data pasien }\end{array}$ & $\begin{array}{l}\text { Jika } \\
\text { pengisian } \\
\text { data } \\
\text { pasien } \\
\text { masuk } \\
\text { semua } \\
\text { datanya }\end{array}$ & $\begin{array}{l}\text { Data } \\
\text { pasie } \\
\mathrm{n} \\
\text { tidak } \\
\text { tersi } \\
\text { mpan }\end{array}$ \\
\hline & $\begin{array}{l}\text { Penguji } \\
\text { an } \\
\text { input } \\
\text { data }\end{array}$ & \begin{tabular}{l}
\multicolumn{2}{c}{ masu } \\
kkan data \\
pendaftara \\
n pasien
\end{tabular} & $\begin{array}{l}\text { Jika } \\
\text { pengisian } \\
\text { data } \\
\text { pendaftar }\end{array}$ & $\begin{array}{l}\text { Data } \\
\text { pend } \\
\text { aftar } \\
\text { an }\end{array}$ \\
\hline
\end{tabular}




\begin{tabular}{|c|c|c|c|c|c|c|c|c|c|}
\hline $\begin{array}{l}N \\
o\end{array}$ & $\begin{array}{l}\text { Yang } \\
\text { Diuji }\end{array}$ & $\begin{array}{l}\text { Proses } \\
\text { Penguji } \\
\text { an }\end{array}$ & $\begin{array}{l}\text { Ekspetas } \\
\text { i } \\
\text { Hasil }\end{array}$ & $\begin{array}{l}\text { Hasi } \\
\text { l } \\
\text { Peng } \\
\text { ujia } \\
\text { n }\end{array}$ & $\begin{array}{l}N \\
o\end{array}$ & $\begin{array}{l}\text { Yang } \\
\text { Diuji }\end{array}$ & $\begin{array}{l}\text { Proses } \\
\text { Penguji } \\
\text { an }\end{array}$ & $\begin{array}{l}\text { Ekspetas } \\
\text { i } \\
\text { Hasil }\end{array}$ & $\begin{array}{l}\text { Hasi } \\
\text { l } \\
\text { Peng } \\
\text { ujia } \\
\text { n }\end{array}$ \\
\hline & $\begin{array}{l}\text { pendaft } \\
\text { aran } \\
\text { pasien }\end{array}$ & & $\begin{array}{l}\text { an pasien } \\
\text { masuk } \\
\text { semua } \\
\text { datanya }\end{array}$ & $\begin{array}{l}\text { pasie } \\
\mathrm{n} \\
\text { tersi } \\
\text { mpan }\end{array}$ & & $\begin{array}{l}\text { ksaan } \\
\text { pasien }\end{array}$ & & $\begin{array}{l}\text { pasien } \\
\text { masuk } \\
\text { semua } \\
\text { datanya }\end{array}$ & $\begin{array}{l}\mathrm{n} \\
\text { tidak } \\
\text { tersi } \\
\text { mpan }\end{array}$ \\
\hline & \multirow[t]{2}{*}{$\begin{array}{l}\text { Penguji } \\
\text { an } \\
\text { input } \\
\text { data } \\
\text { pendaft } \\
\text { aran } \\
\text { pasien }\end{array}$} & \multirow[t]{2}{*}{\begin{tabular}{l}
\multicolumn{2}{c}{ masu } \\
kkan data \\
pendaftara \\
n pasien
\end{tabular}} & \multirow{2}{*}{$\begin{array}{l}\text { Jika } \\
\text { pengisian } \\
\text { data } \\
\text { pendaftar } \\
\text { an pasien } \\
\text { masuk } \\
\text { semua } \\
\text { datanya }\end{array}$} & \multirow[t]{2}{*}{$\begin{array}{l}\text { Data } \\
\text { komp } \\
\text { onen } \\
\text { tidak } \\
\text { tersi } \\
\text { mpan }\end{array}$} & 1 & $\begin{array}{l}\text { Penguji } \\
\text { an } \\
\text { input } \\
\text { data } \\
\text { obat }\end{array}$ & \begin{tabular}{l}
\multicolumn{1}{c}{ masu } \\
kkan t data \\
obat
\end{tabular} & $\begin{array}{l}\text { Jika } \\
\text { pengisian } \\
\text { data tidak } \\
\text { lengkap }\end{array}$ & $\begin{array}{l}\text { Data } \\
\text { obat } \\
\text { tidak } \\
\text { tersi } \\
\text { mpan }\end{array}$ \\
\hline & & & & & 2 & $\begin{array}{l}\text { Tamba } \\
\text { h data } \\
\text { obat }\end{array}$ & $\begin{array}{l}\text { masu } \\
\text { kkan data } \\
\text { obat }\end{array}$ & $\begin{array}{l}\text { Jika data } \\
\text { sudah ada }\end{array}$ & $\begin{array}{l}\text { Data } \\
\text { obat } \\
\text { tidak }\end{array}$ \\
\hline & \multirow{2}{*}{$\begin{array}{l}\text { Penguji } \\
\text { an } \\
\text { input } \\
\text { data } \\
\text { pendaft } \\
\text { aran } \\
\text { pasien }\end{array}$} & \multirow{2}{*}{\begin{tabular}{l}
\multicolumn{2}{c}{ masu } \\
kkan data \\
pendaftara \\
n pasien
\end{tabular}} & \multirow{2}{*}{$\begin{array}{l}\text { Jika } \\
\text { pengisian } \\
\text { data } \\
\text { pendaftar } \\
\text { an pasien } \\
\text { masuk } \\
\text { semua } \\
\text { datanya }\end{array}$} & \multirow{2}{*}{$\begin{array}{l}\text { Data } \\
\text { pend } \\
\text { aftar } \\
\text { an } \\
\text { pasie } \\
\mathrm{n} \\
\text { tidak } \\
\text { tersi } \\
\text { mpan }\end{array}$} & & & & & $\begin{array}{l}\text { tersi } \\
\text { mpan }\end{array}$ \\
\hline & & & & & 3 & $\begin{array}{l}\text { Tamba } \\
\mathrm{h} \text { data } \\
\text { obat }\end{array}$ & $\begin{array}{l}\text { masukkan } \\
\text { data obat }\end{array}$ & $\begin{array}{l}\text { Jika data } \\
\text { sudah ada }\end{array}$ & $\begin{array}{l}\text { Data } \\
\text { obat } \\
\text { tidak } \\
\text { tersi } \\
\text { mpan }\end{array}$ \\
\hline & \multirow{2}{*}{$\begin{array}{l}\text { Penguji } \\
\text { an } \\
\text { input } \\
\text { data } \\
\text { pemeri } \\
\text { ksaan } \\
\text { pasien }\end{array}$} & \multirow[t]{2}{*}{\begin{tabular}{l}
\multicolumn{2}{c}{ masu } \\
kkan data \\
pemeriksa \\
an pasien
\end{tabular}} & \multirow{2}{*}{$\begin{array}{l}\text { Jika } \\
\text { pengisian } \\
\text { data } \\
\text { pemeriks } \\
\text { aan } \\
\text { pasien } \\
\text { masuk } \\
\text { semua } \\
\text { datanya }\end{array}$} & \multirow{2}{*}{$\begin{array}{l}\text { Data } \\
\text { peme } \\
\text { riksa } \\
\text { an } \\
\text { pasie } \\
\mathrm{n} \\
\text { tersi } \\
\text { mpan }\end{array}$} & 4 & $\begin{array}{l}\text { Uji } \\
\text { input } \\
\text { data } \\
\text { gejala }\end{array}$ & \begin{tabular}{l}
\multicolumn{2}{c}{ masu } \\
kkan data \\
gejala
\end{tabular} & $\begin{array}{l}\text { Jika input } \\
\text { data } \\
\text { gejala } \\
\text { sudah } \\
\text { lengkap }\end{array}$ & $\begin{array}{l}\text { Data } \\
\text { gejal } \\
\text { a } \\
\text { tersi } \\
\text { mpan }\end{array}$ \\
\hline & & & & & 5 & $\begin{array}{l}\text { Uji } \\
\text { input } \\
\text { data } \\
\text { gejala }\end{array}$ & \begin{tabular}{l}
\multicolumn{2}{c}{ masu } \\
kkan data \\
gejala
\end{tabular} & $\begin{array}{l}\text { Jika input } \\
\text { data } \\
\text { gejala } \\
\text { tidak } \\
\text { lengkap }\end{array}$ & $\begin{array}{l}\text { Data } \\
\text { gejal } \\
\text { a } \\
\text { tidak } \\
\text { tersi }\end{array}$ \\
\hline & \multirow{2}{*}{$\begin{array}{l}\text { Penguji } \\
\text { an } \\
\text { input } \\
\text { data } \\
\text { pemeri } \\
\text { ksaan } \\
\text { pasien }\end{array}$} & \multirow{2}{*}{\begin{tabular}{l}
\multicolumn{2}{c}{ masu } \\
kkan data \\
pemeriksa \\
an pasien
\end{tabular}} & \multirow{2}{*}{$\begin{array}{l}\text { Jika } \\
\text { pengisian } \\
\text { data } \\
\text { pemeriks } \\
\text { aan } \\
\text { pasien } \\
\text { masuk } \\
\text { semua } \\
\text { datanya }\end{array}$} & \multirow{2}{*}{$\begin{array}{l}\text { Data } \\
\text { komp } \\
\text { onen } \\
\text { tidak } \\
\text { tersi } \\
\text { mpan }\end{array}$} & & & & & mpan \\
\hline & & & & & 6 & $\begin{array}{l}\text { Uji } \\
\text { input } \\
\text { data } \\
\text { gejala }\end{array}$ & \begin{tabular}{l}
\multicolumn{2}{c}{ masu } \\
kkan data \\
gejala
\end{tabular} & $\begin{array}{l}\text { Jika data } \\
\text { gejala } \\
\text { sudah ada }\end{array}$ & $\begin{array}{l}\text { Data } \\
\text { gejal } \\
\text { a } \\
\text { tidak } \\
\text { tersi } \\
\text { mpan }\end{array}$ \\
\hline 0 & $\begin{array}{l}\text { Penguji } \\
\text { an } \\
\text { input } \\
\text { data } \\
\text { pemeri } \\
\end{array}$ & \begin{tabular}{l}
\multicolumn{2}{c}{ masu } \\
kkan data \\
pemeriksa \\
an pasien
\end{tabular} & $\begin{array}{l}\text { Jika } \\
\text { pengisian } \\
\text { data } \\
\text { pemeriks } \\
\text { aan }\end{array}$ & $\begin{array}{l}\text { Data } \\
\text { peme } \\
\text { riksa } \\
\text { an } \\
\text { pasie } \\
\end{array}$ & 7 & $\begin{array}{l}\text { Penguji } \\
\text { an } \\
\text { input } \\
\text { data } \\
\text { pemba } \\
\text { yaran }\end{array}$ & \begin{tabular}{l}
\multicolumn{2}{r}{ masu } \\
kkan data \\
pembayara \\
$\mathrm{n}$
\end{tabular} & $\begin{array}{l}\text { Jika input } \\
\text { data } \\
\text { pembayar } \\
\text { an sudah } \\
\text { benar }\end{array}$ & $\begin{array}{l}\text { Data } \\
\text { pemb } \\
\text { ayara } \\
\mathrm{n} \\
\text { tersi } \\
\text { mpan }\end{array}$ \\
\hline
\end{tabular}

Johnson Sihombing, Irwan Budi Irawan 


\begin{tabular}{|c|c|c|c|c|}
\hline $\begin{array}{l}N \\
o\end{array}$ & $\begin{array}{l}\text { Yang } \\
\text { Diuji }\end{array}$ & $\begin{array}{l}\text { Proses } \\
\text { Penguji } \\
\text { an }\end{array}$ & $\begin{array}{l}\text { Ekspetas } \\
\text { i } \\
\text { Hasil }\end{array}$ & $\begin{array}{l}\text { Hasi } \\
1 \\
\text { Peng } \\
\text { ujia } \\
\text { n } \\
\end{array}$ \\
\hline 8 & $\begin{array}{l}\text { Penguji } \\
\text { an } \\
\text { input } \\
\text { data } \\
\text { pemba } \\
\text { yaran }\end{array}$ & \begin{tabular}{l}
\multicolumn{2}{c}{ masu } \\
kkan data \\
pembayara \\
$n$
\end{tabular} & $\begin{array}{l}\text { Jika } \\
\text { baiaya } \\
\text { pembayar } \\
\text { an yang } \\
\text { diinout } \\
\text { tidak } \\
\text { sesuai }\end{array}$ & $\begin{array}{l}\text { Data } \\
\text { pemb } \\
\text { ayara } \\
\mathrm{n} \\
\text { tidak } \\
\text { tersi } \\
\text { mpan }\end{array}$ \\
\hline 9 & $\begin{array}{l}\text { Penguji } \\
\text { an } \\
\text { input } \\
\text { data } \\
\text { pemba } \\
\text { yaran }\end{array}$ & \begin{tabular}{l}
\multicolumn{2}{c}{ masu } \\
kkan data \\
pembayara \\
$\mathrm{n}$
\end{tabular} & \begin{tabular}{l}
\multicolumn{2}{c}{ Jika } \\
input data \\
pembayara \\
n sudah ada
\end{tabular} & $\begin{array}{l}\text { Data } \\
\text { pemb } \\
\text { ayara } \\
\mathrm{n} \\
\text { tidak } \\
\text { tersi } \\
\text { mpan }\end{array}$ \\
\hline
\end{tabular}

\section{KESIMPULAN DAN SARAN}

\section{V.1 Kesimpulan}

Setelah penulis melakukan semua tahapan mulai dari pendefinisian masalah hingga tahap pengujian, maka penulis membuat beberapa kesimpulan sebagai berikut:

1. Aplikasi sistem informasi pendaftaran pasien merupakan sebuah aplikasi yang dibuat dengan bantuan teknologi komputer yang memudahkan pihak klinik untuk pengolahan data pendaftaran pasien.

2. Dengan telah dibuatnya aplikasi sistem informasi pendaftaran pasien ini, klinik mampu menyajikan informasi tentang jumlah kunjungan pasien, data kronologis pasien, da ta pemakaian obat untuk pasien, dan lain-lain.

3. Memudahkan petugas administrasi untuk membuat laporan pendaftaran dan kunjungan pasien.

Saran-saran yang penulis harapkan untuk pengembangan sistem di masa mendatang :

1. Pengolahan data pendaftaran pasien yang telah ada sebaiknya didukung dengan spesifikasi perangkat keras yang sesuai perkembangan jaman.

2. Sistem informasi administrasi pendaftaran pasien ini diharapkan dapat mengevaluasi pengelolaan data pendaftaran pasien untuk kepentingan manajerial.

3. Aktivitas back-up data pendaftaran pasien secara periodik agarselalau menampilkan data yang mutakir.

4. Melakukan proteksi terhadap sistem informasi presensi guna menghindari terjadinya manipulasi data.

Dibutuhkan seorang staf khusus yang mengerti bidang teknologi informasi, khususnya sistem informasi administrasi pendaftaran pasien guna mendukung operasional sistem yang berjalan.

\section{REFERENSI}

Peraturan Menteri Kesehatan Republik Indoneia Nomor 9 Tahun 2014. Tentang Klinik. Jakarta: DepKes RI.

Sabarguna, Boy Subirosa, Dr.dr, MARS. (2009). Keselamatan dan Keamanan pada Rekam Medis Terkomputerisasi. Jakarta: Universitas Indonesia (UI-Press)

Hidayatullah, Priyanto. (2014). Visual Basic.Net. Bandung: Informatika Bandung

Andriani, Lidya. (2009). Sistem Informasi Pendaftaran Pasien Rawat Jalan Di Rumah Sakit Dengan Menggunakan Program Komputer. Fakultas Kesehatan Masyarakat Universitas Sumatera Utara. Jurnal Skripsi.

Rahayu, Primita S dkk. (2011). Sistem Informasi Pasien Rawat Jalan Puskesmas Maospati Berbasis Web. Politeknik Telkom Bandung. Jurnal

Raymond McLeod, Jr. (2005). Sistem Informasi Manajemen : Studi Sistem Informasi Berbasis Komputer. PT. Prenhallindo. Jakarta

Wardianto. (2011). Rancang Bangyun Aplikasi Pendaftaran Online Jasa Pengobatan Berbasis Multimedia Pada Klinik Utama Aksar Depok

Sangadji, Dr. Etta Mamang, dan Dr. Sopiah, M.M.,S.Pd. (2010). Metodologi Penelitian- 
Pendekatan Praktis dalam Penelitian. Yogyakarta : C.V. Andi Offset.

Abdullah \& Iswandi. (2015).. Sistem Pendaftaran Online Pasien Pada Klinik Dengan Metode First In Firstn Out (FIFO) Berbasis Web Service

Oetomo, Budi Sutedjo Dharma. 2002. Perencanaan \& Pembangunan Sistem Informasi. Yogyakarta: ANDI.

Rustiyanto, Ery. (2011). Sistem Informasi Manajmen Rumah Sakit yang Terintegrasi. Yogyakarta: Gosyen Publishing

Hakam, Fahmi. (2015). Perancangan Sistem Informasi Rekam Medis Di Klinik Griya Medika Menggunakan Metode Prototyping. ISSN: 20869185. Jurnal Permata Indonesia Vol. 6, No.1 Mei 2015: 29-36. Diambil dari: http://www.permataindonesia.ac.id/wpcontent/upl oads/2015/07/04.-Jurnal-PI_Fahmi.pdf 18 April 2017)

Aprianti, Winda dan Witri Sari Nurfajriyah. (2016). Sistem Informasi Geografi Pelayanan Kesehatan Kecamatan Pelaihari Berbasis Web. ISSN: 2460173X. Jurnal Sains \& Informatika Vol.2, No.2 November 2016: 116-121. Diambil dari: http://jurnal.politala.ac.id/index.php/JSI/arti cle/view/137/114 (14 April 2017) 